ISSN: 2224-0616

Int. J. Agril. Res. Innov. \& Tech. 7 (2): 27-35, December, 2017 Available online at http:// www.ijarit.webs.com

\title{
STUDY ON ABUNDANCE OF BENTHIC MACRO-INVERTEBRATES IN RELATION TO SOIL TEXTURE TYPES OF SEDIMENT IN THREE PONDS
}

\author{
B.R. Irin', M.A. Mansur ${ }^{2 *}$ and M.S. Rahman ${ }^{3}$ \\ Received 1 August 2017, Revised 10 October 2017, Accepted 24 December 2017, Published online 31 December 2017
}

\begin{abstract}
The present research was conducted to evaluate the monthly variations of macrozoobenthos of three ponds (pond 1, bottom soil is loam; pond 2, bottom soil is sandy loam; pond 3, bottom soil is silty clay loam) in relation to soil texture types of sediment. The major groups of macro-zoobenthos recorded were Chironomidae, Oligochaeta, Mollusca and Ceratopogonidae. The values of all water quality parameters such as temperature, water depth, rainfall, transparency, dissolved oxygen, $\mathrm{pH}$, free $\mathrm{CO}_{2}, \mathrm{NO}_{3}-\mathrm{N}$ and $\mathrm{PO}_{4}-\mathrm{P}$ were found to have positive correlations in most cases, in some cases negative correlations and in few cases significant correlations. The abundance of Chironomidae was to be dominant in the pond no. 3 during the whole study period. The highest number of Oligochaeta ( 400 per $\mathrm{m}^{2}$ ) was found in pond no. 3 at depth of $150 \mathrm{~cm}$ and the lowest number of Oligochaeta $(0$ per m²) was found in pond nos. 1, 2 and 3 at both depths. The highest number of Chironomidae (1332 per $\mathrm{m}^{2}$ ) was found in pond no. 3 at depth of $150 \mathrm{~cm}$ and the lowest number of Chironomidae (444 per $\mathrm{m}^{2}$ ) was found in pond no. 2 at depth of $100 \mathrm{~cm}$. The highest number of Ceratopogonidae (977 per $\mathrm{m}^{2}$ ) was found in pond no. 3 at the depth of $150 \mathrm{~cm}$ and the lowest number of Ceratopogonidae $\left(178\right.$ per $\left.\mathrm{m}^{2}\right)$ was found in pond no. 2 at both depths. The highest number of Mollusca (1288 per $\mathrm{m}^{2}$ ) was found in pond no. 3 at the depth of $150 \mathrm{~cm}$ and the lowest number of Mollusca (222 per $\mathrm{m}^{2}$ ) was found in pond no. 2 at the depth of $100 \mathrm{~cm}$. Satisfactory quantity of macrobenthos in the pond no. 3 at the depth of 150 $\mathrm{cm}$ than those of other two ponds. Between 2 depths $(100$ and $150 \mathrm{~cm})$, the depth of $150 \mathrm{~cm}$ was to have highest quantity of macro-zoobenthos in all the three ponds because this depth was most favourable for macro-zoobenthos production. In pond no. 1, 2 and 3 relation of macro-benthos (no. per $\mathrm{m}^{2}$ ) with chemical parameters of pond bottom-soil conditions vary pond to pond which influence primary production and also influence macro-zoobenthos production (secondary production). The highest macro-zoobenthos population density was found in pond no. 3 followed by pond no. 1 and the lowest production in pond no. 2 but macro-zoobenthos production in pond no. 2 and pond no. 1 are more or less similar and macro-zoobenthos production in pond no. 3 is different and higher than those of pond nos. 1 and 2 which indicates that silty clay loam of bottom-soil is more suitable for macrozoobenthos than other soil textural classes of bottom-soil loam and sandy loam.
\end{abstract}

Keywords: Macro-zoobenthos, Loam Bottom, Sandy Loam Bottom, Silty Clay Bottom, Pond, Depth

\footnotetext{
${ }^{1}$ Upazilla Fisheries Officer, Deptt. of Fisheries, Ministry of Fisheries and Livestock, Govt. of the People's Republic of Bangladesh. ${ }^{2}$ Department of Fisheries Technology, Faculty of Fisheries, Bangladesh Agricultural University, Mymensingh-2202, Bangladesh.

${ }^{3}$ Department of Fisheries Management, Faculty of Fisheries, Bangladesh Agricultural University, Mymensingh-2202. (Recently retired)

*Corresponding author's email: mansurft63@gmail.com (M.A. Mansur)
}

\section{Introduction}

Benthos is defined as that assemblage of animal living in or on the sediments and dependent upon the decomposition cycle of organic matters which are the basic food supply in any aquatic ecosystem (Brinkhurst, 1974). Benthos is important food item of fishes as well as an indicator of productivity of a water body (Dewan, 1973).

Benthic invertebrates are important part in aquatic ecosystems. Investigations of zoobenthos can provide a lot of information about the state of water body. Study of benthos is very important because different kinds of macro-zoobenthos are very important food organisms for bottomfeeding fishes; they are important in sedimentwater interactions; micro-benthos (bacteria and other microbes) increase and recycle nutrients for phytoplankton through decomposition of dead organic matter; the presence and abundance of benthos indicates normal limnological conditions of the water bodies; and they are also occasional zooplankton i.e. they are also used as food by fishes of upper water and mid-water and column water. 
Many researchers termed the bottom soil as "The chemical laboratory of the pond"; where nutrients, required for productivity of waters, are released through chemical and biochemical processes from organic matters and minerals of the soil. The nutrients status of both soil and water plays a significant role in the growth and abundance of aquatic organisms, specially plankton and benthos. Thus, the physicochemical characteristics of pond water and soil are of great importance for fish culture and fisheries management. Moreover, the benthic fauna, through their burrowing and feeding activities play a significant role in the exchange of nutrients, dissolved gases and other materials between sediments and overlying water (Nupur, 2011).

The work on depth wise and pond wise variation of benthos, the combined effect of bottom soil properties on the benthos, their interaction and intra-relations based on statistical analysis, are very rare. The productivity of a water body largely depends upon the plankton and benthos (Habib et al., 1984).

The growth of fish depends largely upon the availability of food organisms namely plankton and benthos. Benthos is one of very important food item of fishes especially the bottom feeders. About $60 \%$ of total food items of fishes come from insect larvae.

The growth and abundance of benthic fauna depend upon the physico-chemical properties of bottom soil. The chemical properties (nutrient status) have some growth promoting effect on the various species of benthos fauna.

The diversity, biomass and abundance of benthos depend upon environmental factors of their habitat. The density and biomass of aquatic invertebrates correlated with water hardness and carbonate hardness also (Bernotiene and Visinskiene, 2007).

Oligochaeta, Chironomidae and Mollusca are the dominant macro-benthos in tropical freshwater ponds. And Oligochaeta is the most dominant group followed by Chironomidae and Mollusca (Das and Islam, 1983).Three major groups of benthic macro-invertebrate namely, Chironomids, Oligochaetes, and Molluscs formed the bulk of the population and Oligochaetes are the most dominant group followed by Chironomidae and Molluscs in the campus of Bangladesh Agricultural University, Mymensingh (Khan, 1990).

A large number of research work have been conducted on macro-zoobenthos and relations and effects of different aquatic parameters on the macro-zoobenthos in ponds, lakes, reservoirs, estuaries, rivers and other water bodies. However, considering the great significance of benthos for productivity and suitability of water bodies the present research was planned with the objectives of: Quantitative study of macrozoobenthos at two depths of water of three ponds in relation to limnological conditions; study of limnological conditions of water and pond bottom-soil of three ponds; determination of monthly fluctuation of macro-zoobenthos at two depths of water of three ponds.

\section{Materials and Methods}

This research study was conducted in three ponds situated at the campus of Bangladesh Agricultural University, Mymensingh.

\section{Description of the ponds}

Three artificial perennial ponds, situated in the campus of Bangladesh Agricultural University, Mymensingh, were selected for the study. The ponds were arbitrarily numbered as pond no. 1 , pond no. 2, and pond no. 3 for the sake of recording of data and reporting the results.

Pond no. 1: It is an experimental pond of the Deptt. of Fisheries Biology and Genetics situated to the North of the Fisheries Faculty Buildings. The pond is rectangular shaped having an area (without embankment) of 0.25 acres (0.099 hectare or $989 \mathrm{~m}^{2}$ ) and an average depth of 0.93 $\mathrm{m}$. The soil textural class of bottom soil (sediment) of this pond is loam. It receives water mainly from rainfall and also from water supply system of a deep tube-well of the Faculty of Fisheries.

Pond no. 2: This pond is situated along the Dhaka-Mymensingh Rail line/ Railway in the BAU Campus '0' point (locally called Jabber's Moor) with an area (without embankment) of 2.086 acres (1.186 hectare or $11860.187 \mathrm{~m}^{2}$ ) and an average water depth of $0.96 \mathrm{~m}$. The pond is rectangular in shape with unbroken regular embankment. The water was always clear and free from floating vegetation. The soil textural class of bottom soil (sediment) of the pond is sandy loam. This pond is mainly rainfed.

Pond no. 3: It is an experimental pond of Field Laboratory Complex (Hatchery Complex) of the Faculty of Fisheries. The pond is rectangular shaped having an area (without embankment) of 0.096 acres $\left(0.039\right.$ hectare or $\left.390.625 \mathrm{~m}^{2}\right)$ and an average water depth of $0.85 \mathrm{~m}$. The soil textural class of bottom soil (sediment) of the pond is silty clay loam. It receives water mainly from deep tube-well and from rainfall. 


\section{Sampling and estimation of limnological conditions:}

Monthly sampling was conducted from three ponds on first and fifteenth days of each month during March to September 2012. The experimental layout for study of benthos in three ponds has been presented in Table 1.

1) Data of air temperature $\left({ }^{\circ} \mathrm{C}\right)$, water temperature $\left({ }^{\circ} \mathrm{C}\right)$ and rainfall were collected from weather yard of BAU, Mymensingh.

2) Transparency $(\mathrm{cm})$ of water of 3 ponds were determined by Secchi disk.
3) Water depth in Pond no. 1, Pond no. 2, and Pond no. 3 were measured with a graduated wooden depth meter (meter scale).

4) Dissolved Oxygen (DO) was estimated by a D.O. meter (S.M. 600, Smart D.O. meter, Milwaukee, Made in Italy).

5) Free carbon dioxide of water was determined by titrimetric method using phenolphthalein and $0.0227 \mathrm{~N} \mathrm{NaOH}$ titrant (APHA, 1971).

6) Phosphate phosphorus of water determined by a portable phosphate meter (Model number-II 93717 Hanna Instruments Co.

Table 1. The experimental layout for study of benthos in three ponds.

\begin{tabular}{|c|c|c|c|c|}
\hline $\begin{array}{l}\text { Treatment } \\
\text { (Pond no.) }\end{array}$ & $\begin{array}{l}\text { Area, av. depth, } \\
\text { shape of the pond }\end{array}$ & $\begin{array}{l}\text { Textural class of } \\
\text { bottom soil } \\
\text { (sediment) }\end{array}$ & $\begin{array}{l}\text { Source of water of } \\
\text { the pond }\end{array}$ & $\begin{array}{l}\text { Replication } \\
\text { (at water depth) }\end{array}$ \\
\hline $\begin{array}{l}\text { Treatment-1 } \\
\text { (Pond no.1) }\end{array}$ & $\begin{array}{l}989 \mathrm{~m}^{2} \\
0.93 \mathrm{~m} \\
\text { rectanqular }\end{array}$ & Loam & $\begin{array}{l}\text { Rain water \& deep- } \\
\text { tube well }\end{array}$ & $\begin{array}{l}100 \mathrm{~cm} ; \\
\text { and } 150 \mathrm{~cm}\end{array}$ \\
\hline $\begin{array}{l}\text { Treatment-2 } \\
\text { (Pond no. 2) }\end{array}$ & $\begin{array}{l}11860.187 \mathrm{~m}^{2} \\
0.96 \mathrm{~m} \\
\text { rectanqular }\end{array}$ & Sandy loam & Rain water & $\begin{array}{l}100 \mathrm{~cm} \text {; } \\
\text { and } 150 \mathrm{~cm}\end{array}$ \\
\hline $\begin{array}{l}\text { Treatment-3 } \\
\text { (Pond no. 3) }\end{array}$ & $\begin{array}{l}390.625 \mathrm{~m}^{2} \\
0.85 \mathrm{~m} \\
\text { rectanqular }\end{array}$ & Silty clay loam & $\begin{array}{l}\text { Rain water \& deep- } \\
\text { tube well }\end{array}$ & $\begin{array}{l}100 \mathrm{~cm} \text {; } \\
\text { and } 150 \mathrm{~cm}\end{array}$ \\
\hline
\end{tabular}

Determination of textural class and chemical status of pond bottom-soil (sediment):

1) Estimation of soil textural class of the pond bottom soil (sediment) collected by an Ekman dredge was done fortnightly by the Finger Feel Method (Sattar and Rahman, 1987).

2) $\mathrm{pH}$ measurement of pond bottom soil (sediment) was performed using a $\mathrm{pH}$ meter of Hanna Instruments Co. (Sattar and Rahman, 1987).

3) Determination of available phosphorus (ppm) of pond bottom-soil (sediment) was done by sodium bicarbonate method (Sattar and Rahman, 1987).

4) Estimation of total nitrogen (\%) of pond bottom-soil (sediment) was done by semi micro-kjeldahl method (Sattar and Rahman, 1987).

5) Estimation of organic carbon (\%) of pond bottom-soil (sediment) was done by Walkley and Black method (Sattar and Rahman, 1987).

\section{Study of benthos (macro-zoobenthos)}

Collection of samples was conducted twice a month. Benthos samples were collected around 11.00 a.m. from two depths $(100 \mathrm{~cm}, 150 \mathrm{~cm})$ of each of three ponds on each sampling day. The samples were collected randomly from 2 depths of water of each of the ponds by lowering an open
Ekman dredge on bottom mud. Then collected benthos with mud was put on a fine mesh-screen net fixed with a small steel frame and mud was washed in the pond water and the bottom materials were passed through a $0.2 \mathrm{~mm}$ meshscreen net for a preliminary separation of benthos and large particles from mud and water. The benthic organisms remained on the screen net were collected from the residue by means of fine forceps and kept into small plastic bottles containing 5\% formalin for preservation. The small plastic bottles were marked properly with a marker pen and taken to the laboratory for laboratory analysis.

\section{Separation and identification of benthic (macro-zoobenthos) samples}

The preserved samples were washed with tap water in a petr idish. Then the samples were cleaned with distilled water. Benthic organisms were then separated from each other using needle and forcep, which were again sorted into major taxonomic groups with the help of hand lens and low power microscope. Then the organisms were identified and counted. To determine macrozoobenthos population density the following formula was used.

Formula for determination of macro-zoobenthos population density (no. per $\mathrm{m}^{2}$ ) according to Rahman (1992). 
Macro-zoobenthos population density (no. per $\mathrm{m}^{2}$ )

$=$ no. found in bottom-mud collected by

Ekman dredge $\mathrm{x} 44.44$

$=$ no. per $225 \mathrm{~cm}^{2}$ x 44.44

where,

Area of open mouth of Ekman dredge $=225 \mathrm{~cm}^{2}$

\section{Results and Discussion}

\section{Physical parameters of water}

Range and average water temperature $\left({ }^{\circ} \mathrm{C}\right)$ during the experimental period in pond nos. 1, 2 and 3 were $\quad 21.4-31^{\circ} \mathrm{C} \quad\left(26.28 \pm 3.44^{\circ} \mathrm{C}\right), \quad 21.5-31^{\circ} \mathrm{C}$ $\left(26.25 \pm 3.30^{\circ} \mathrm{C}\right)$ and $21.30^{\circ} \mathrm{C}\left(26.17 \pm 3.22^{\circ} \mathrm{C}\right)$ respectively (Table 2).

Mean of maximum, minimum and average air temperature on monthly sampling of pond nos. 1, 2 and 3 were $30.63 \pm 1.74,22.2 \pm 4.47$ and $26.37 \pm 2.66\left({ }^{\circ} \mathrm{C}\right)$ during the experimental period (Table 2).

Ranges of pond depth and mean depth during the experimental period in pond nos. 1, 2 and 3 were 0.91-0.94 m (0.926 $\pm 0.013 \mathrm{~m}), 0.94-0.97 \mathrm{~m}$
$(0.957 \pm 0.009 \mathrm{~m}), 0.84-0.86 \mathrm{~m}(0.85 \pm 0.008 \mathrm{~m})$, respectively (Table 2).

Monthly fluctuations of the transparency $(\mathrm{cm})$ of water of 3 different ponds and ranges and mean transparency $(\mathrm{cm})$ during the experimental period in pond nos. 1,2 and 3 were $31.0-32.5 \mathrm{~cm}$ $(32.286 \pm 0.906 \mathrm{~cm}), 14-17 \mathrm{~cm}(16 \pm 1.154 \mathrm{~cm})$, and

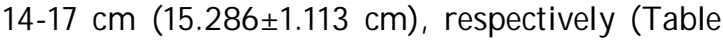
2).

Monthly rainfall (mm) values were same for three ponds. Mean per day of total rainfall of each of 7 months were 16.250, 74.856, 11.861, 4.683, $0.043,1.071$ and $0.0 \mathrm{~mm}$, respectively during the experimental period (Table 2).

\section{Chemical parameters of water}

The ranges and mean of dissolved oxygen during the 7 months experimental period in pond nos. 1, 2 and 3 were 7.5-8.0 ppm (7.86 $\pm 0.24 \mathrm{ppm}), 6.0$ $8.0 \mathrm{ppm}(7.21 \pm 0.70 \mathrm{ppm})$ and $5.0-6.5 \mathrm{ppm}$ (5.86 \pm 0.48$)$, respectively (Table 3$)$. Range and mean of free $\mathrm{CO}_{2}$ (ppm) during the 7 months experimental period in pond nos. 1, 2 and 3 were $3-5 \mathrm{ppm}(3.86 \pm 0.90 \mathrm{ppm}), 0-5 \mathrm{ppm}(3.43 \pm 1.62$ $\mathrm{ppm})$ and $3-5 \mathrm{ppm}(4.00 \pm 0.82 \mathrm{ppm})$, respectively (Table 3).

Table 2. Monthly fluctuation of water temperature, air temperature, water depth, transparency and rainfall (Physical factors) of three ponds during March to September 2012.

\begin{tabular}{|c|c|c|c|c|c|c|c|c|}
\hline \multirow{2}{*}{$\begin{array}{l}\text { Pond } \\
\text { no. }\end{array}$} & \multirow{2}{*}{$\begin{array}{l}\text { Sampling } \\
\text { months }\end{array}$} & \multirow{2}{*}{$\begin{array}{l}\text { Water } \\
\text { temperature } \\
\left({ }^{0} \mathrm{C}\right)\end{array}$} & \multicolumn{3}{|c|}{ Air temperature $\left({ }^{0} \mathrm{C}\right)$} & \multirow{2}{*}{$\begin{array}{l}\text { Mean } \\
\text { depth of } \\
\text { pond (m) }\end{array}$} & \multirow{2}{*}{$\begin{array}{l}\text { Transpare } \\
\text { ncy }(\mathrm{cm})\end{array}$} & \multirow{2}{*}{$\begin{array}{l}\text { Total rainfall } \\
\text { of the month } \\
\text { (mean per day) } \\
\text { (mm) }\end{array}$} \\
\hline & & & Maximum & Minimum & Mean & & & \\
\hline \multirow{8}{*}{ P.1 } & March & 21.4 & 29.27 & 14.5 & 22.1 & 0.93 & 32 & $310.25(17.34)$ \\
\hline & April & 22.1 & 29.2 & 17.4 & 23.3 & 0.92 & 34 & $125.7(7.85)$ \\
\hline & May & 27.2 & 33.0 & 23.2 & 28.1 & 0.94 & 32.5 & $154.2(11.86)$ \\
\hline & June & 26.7 & 28.8 & 24.2 & 26.5 & 0.91 & 32 & 56.19 (4.68) \\
\hline & July & 31.0 & 32.7 & 26.0 & 29.3 & 0.93 & 32.5 & $0.6(.043)$ \\
\hline & August & 26.8 & 30.0 & 24.0 & 27.0 & 0.91 & 21 & 15.0 (1.07) \\
\hline & Sept. & 28.9 & 31.5 & 26.1 & 28.3 & 0.94 & 32 & $0.230(.013)$ \\
\hline & Mean \pm S.D. & $26.286 \pm 3.44$ & $30.63 \pm 1.74$ & $22.2 \pm 4.47$ & $26.37 \pm 2.6$ & $0.92 \pm 01$ & $32.28 \pm 9$ & $(5.966 \pm 6.32)$ \\
\hline \multirow{7}{*}{ P.2 } & March & 21.5 & 29.2 & 14.5 & 22.1 & 0.96 & 17 & 310.25 (17.34) \\
\hline & April & 22.4 & 33.0 & 17.4 & 23.3 & 0.95 & 14 & 125.7(7.85) \\
\hline & May & 27.3 & 28.8 & 23.2 & 28.1 & 0.94 & 16 & $154.2(11.86)$ \\
\hline & J une & 26.8 & 32.7 & 24.2 & 26.5 & 0.96 & 15 & $56.19(4.68)$ \\
\hline & July & 31.0 & 30.0 & 26.0 & 29.3 & 0.97 & 17 & $0.6(.043)$ \\
\hline & August & 26.5 & 31.5 & 24.0 & 27.0 & 0.96 & 16 & 15.0 (1.07) \\
\hline & Sept. & 28.3 & 31.5 & 26.1 & 28.3 & 0.96 & 17 & $0.230(.013)$ \\
\hline \multirow{9}{*}{ P.3 } & Mean \pm S.D. & $26.25 \pm 3.30$ & $30.63 \pm 1.7$ & $22.2 \pm 4.47$ & $26.37 \pm 2.6$ & $0.95 \pm 09$ & $16 \pm 1.15$ & $(5.966 \pm 6.32)$ \\
\hline & March & 21.1 & 29.27 & 14.5 & 22.1 & 0.85 & 14 & 310.25 (17.34) \\
\hline & April & 22.5 & 29.2 & 17.4 & 23.3 & 0.84 & 15 & 125.7(7.85) \\
\hline & May & 27.4 & 33.0 & 23.2 & 28.1 & 0.84 & 17 & $154.2(11.86)$ \\
\hline & June & 26.6 & 28.8 & 24.2 & 26.5 & 0.85 & 16 & 56.19 (4.68) \\
\hline & July & 30.0 & 32.7 & 26.0 & 29.3 & 0.85 & 14 & $0.6(.043)$ \\
\hline & August & 26.9 & 30.0 & 24.0 & 27.0 & 0.86 & 16 & 15.0 (1.07) \\
\hline & Sept. & 28.7 & 28.8 & 26.1 & 28.3 & 0.86 & 15 & $0.230(.013)$ \\
\hline & Mean \pm S.D. & $26.17 \pm 3.22$ & $30.63 \pm 1.74$ & $22.2 \pm 4.47$ & $26.37 \pm 2.6$ & $0.85 \pm 08$ & $15.28 \pm 1$ & $(5.966 \pm 6.32)$ \\
\hline
\end{tabular}


The ranges and mean of total alkalinity (ppm) found during the 7 months experimental period in pond nos 1, 2 and 3 were $72-78$ ppm (75.14 $\pm 2.19 \mathrm{ppm}), 82-86 \mathrm{ppm}(84.57 \pm 1.98)$ and 74-79 ppm ( $76.57 \pm 1.71 \mathrm{ppm})$, respectively (Table $3)$.

Ranges and mean of phosphate phosphorus (ppm) during the experimental period in pond nos. 1,2 and 3 were $0.3-0.9 \mathrm{ppm}(0.62 \pm 0.23$ $\mathrm{ppm}), 0.3-0.7 \mathrm{ppm}(0.46 \pm 0.15 \mathrm{ppm})$ and 0.1-0.9 ppm $(0.69 \pm 0.26 \mathrm{ppm})$, respectively (Table 3$)$.
Ranges and mean of nitrate nitrogen (ppm) during the experimental period in pond nos. 1,2 and 3 were $1.2-1.6 \mathrm{ppm}(1.37 \pm 0.23 \mathrm{ppm}), 1.2-1.8$ ppm $(1.58 \pm 0.19 \mathrm{ppm})$ and 1.1-1.9 ppm $(1.5 \pm 0.26$ ppm), respectively (Table 3 ).

\section{Physical and chemical parameters of pond bottom-soil}

The soil textural classes of pond bottom-soil of pond nos. 1, 2 and 3 were loam, sandy loam, silty clay loam, respectively (Table 4, 5 and 6).

Table 3. Monthly fluctuation of dissolved oxygen, free carbon dioxide, total alkalinity, $\mathrm{PO}_{4}-\mathrm{P}(\mathrm{ppm})$ and $\mathrm{NO}_{3}-\mathrm{N}$ (ppm) (chemical factors) of water of three ponds during March to September 2012.

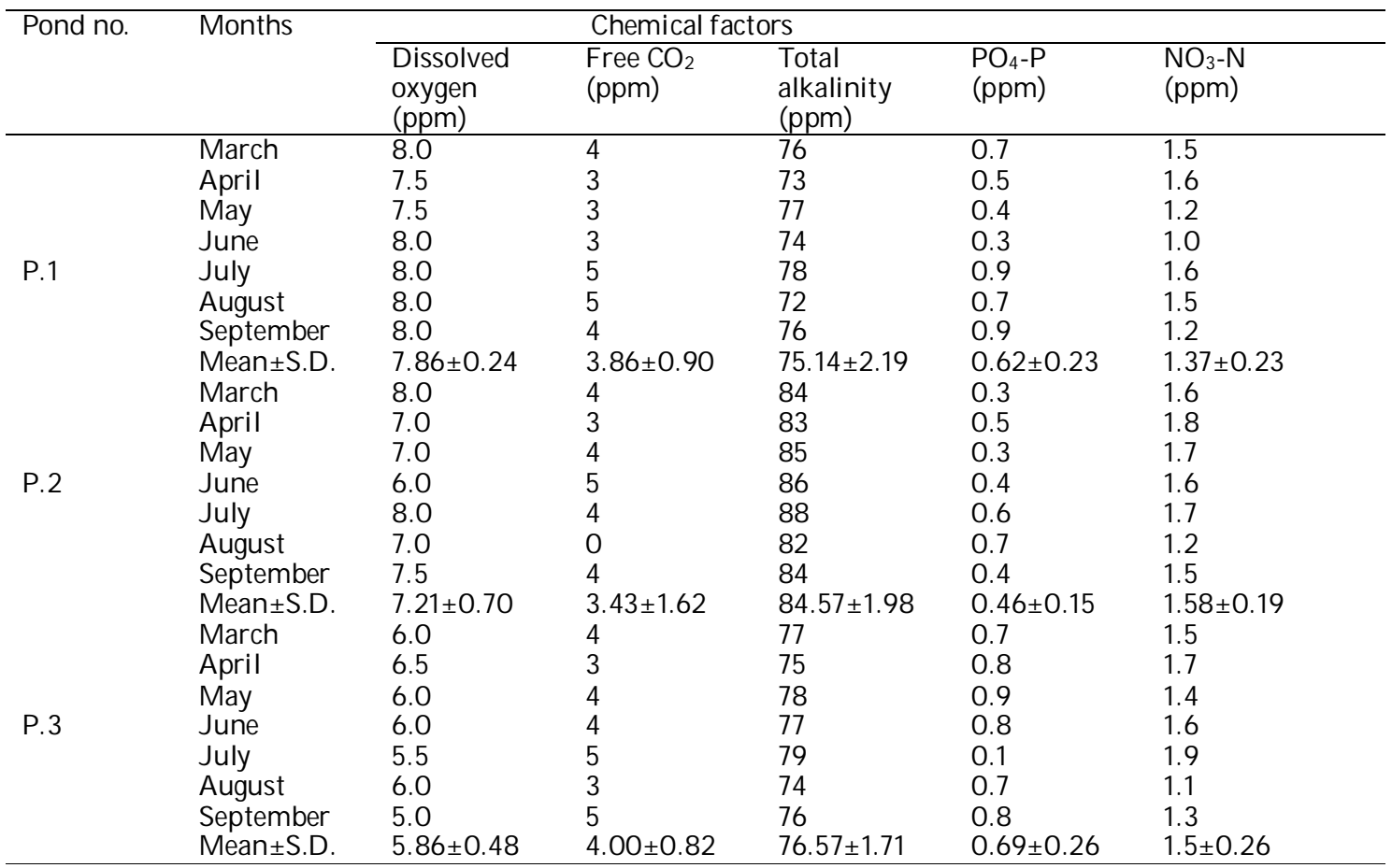

Monthly mean of $\mathrm{pH}$ of pond bottom soil of two depths of each of three ponds $(100 \mathrm{~cm}, 150 \mathrm{~cm})$ during the months of March to September in pond no. 1 were 6.17, 6.29, 6.32 and 6.22; those in pond no.2 were $6.09,6.22,6.19,6.29,6.18,6.19$ and 6.19 and those in pond no. 3 were $6.13,6.18$, $6.26,6.18,6.24,6.28$ and 6.33 , respectively (Table 4, 5 and 6). Monthly mean of organic carbon (\%) of pond bottom-soil of two depths of water of each pond $(100 \mathrm{~cm}, 150 \mathrm{~cm})$ during March to September in pond no. 1 were 0.64 , $0.70,0.92,0.90,0.68,0.69$ and 0.67 ; those in pond no. 2 were 1.29, 2.1, 1.22, 1.32, 1.30, 1.88 and 1.61; and those in pond no. 3 were 1.69, 1.33, 1.31, 1.48, 1.72, 1.61 and 1.69 (Table 4, 5 and 6).

Monthly mean of organic matter (\%) of pond bottom-soil of two depths of water of each pond $(100 \mathrm{~cm}, 150 \mathrm{~cm})$ during Match to September in pond no. 1 were 1.12, 1.22, 1.59, 1.56, 1.18, 1.19 and 1.17; those in pond no. 2 were $2.23,2.13,2.11$,
$2.28,2.26,3.26$ and 2.78; and those in pond no. 3 were $2.93,2.31,2.26,2.56,2.97,2.78$ and 2.46 (Table 4, 5 and 6).

Monthly mean of available phosphorus (ppm) of pond bottom-soil of two depths of water of each pond $(100 \mathrm{~cm}, 150 \mathrm{~cm})$ during March to September in pond no. 1 were 9.92, 10.01, 11.18, 10.89, 11.07, 9.17 and 9.49; those in pond no. 2 were $9.82,9.76,10.44,12.04,8.72,9.08$ and 14.11; and those in pond no. 3 were 15.29, 13.07, 12.53, 5.71, 8.27, 9.18 and 12.08 (Table 4, 5 and $6)$.

The mean values for total nitrogen (\%) of pond bottom soil of two depths $(100 \mathrm{~cm}, 150 \mathrm{~cm})$ of three ponds were in pond no.1 0.058, 0.068, $0.072,0.083,0.062,0.060$, and 0.068 ; those in pond no. 2 were $0.117,0.116,0.118,0.120,0.120$, 0.136 and 0.169 ; those in pond no. 3 were 0.149 , $0.177,0.200,0.156,0.126,0.080$ and 0.150 (Table 4, 5 and 6). 
Table 4. Monthly physico-chemical conditions of pond bottom-soil (sediments) of pond no. 1 at two depths $(100 \mathrm{~cm}, 150 \mathrm{~cm})$ during the period of March to September 2012.

\begin{tabular}{|c|c|c|c|c|c|c|c|}
\hline \multirow[t]{2}{*}{ Months } & \multicolumn{2}{|c|}{ Physical factors } & \multicolumn{4}{|c|}{ Chemical factors } & \multirow[b]{2}{*}{$\begin{array}{c}\text { Total } \\
\text { nitrogen } \\
(\%)\end{array}$} \\
\hline & $\begin{array}{l}\text { Sampling } \\
\text { depth } \\
\text { (cm) }\end{array}$ & $\begin{array}{l}\text { Soil } \\
\text { textural } \\
\text { class }\end{array}$ & $\mathrm{pH}$ & $\begin{array}{l}\text { Organic } \\
\text { carbon } \\
(\%)\end{array}$ & $\begin{array}{c}\text { Organic } \\
\text { matter } \\
(\%)\end{array}$ & $\begin{array}{c}\text { Available } \\
\text { phosphorus } \\
\text { (ppm) }\end{array}$ & \\
\hline \multirow{4}{*}{ March } & 100 & Loam & 6.16 & 0.766 & 1.325 & 9.428 & 0.068 \\
\hline & 150 & Loam & 6.26 & 0.529 & 0.915 & 10.431 & 0.048 \\
\hline & Mean & - & 6.21 & 0.648 & 1.12 & 9.929 & 0.058 \\
\hline & 100 & Loam & 6.37 & 0.758 & 1.311 & 9.68 & 0.064 \\
\hline \multirow[t]{3}{*}{ April } & 150 & Loam & 6.36 & 0.656 & 1.134 & 10.344 & 0.072 \\
\hline & Mean & - & 6.365 & 0.707 & 1.222 & 10.012 & 0.068 \\
\hline & 100 & Loam & 6.18 & 0.893 & 1.545 & 11.033 & 0.068 \\
\hline \multirow[t]{3}{*}{ May } & 150 & Loam & 6.24 & 0.948 & 1.640 & 11.334 & 0.076 \\
\hline & Mean & - & 6.21 & 0.920 & 1.595 & 11.183 & 0.072 \\
\hline & 100 & Loam & 6.16 & 0.882 & 1.526 & 10.564 & 0.080 \\
\hline \multirow[t]{3}{*}{ June } & 150 & Loam & 6.18 & 0.925 & 1.600 & 11.226 & 0.086 \\
\hline & Mean & - & 6.17 & 0.903 & 1.563 & 10.895 & 0.083 \\
\hline & 100 & Loam & 6.24 & 0.584 & 1.010 & 10.944 & 0.058 \\
\hline \multirow[t]{3}{*}{ July } & 150 & Loam & 6.34 & 0.784 & 1.356 & 11.212 & 0.067 \\
\hline & Mean & - & 6.29 & 0.684 & 1.183 & 11.078 & 0.062 \\
\hline & 100 & Loam & 6.36 & 0.642 & 1.111 & 8.224 & 0.050 \\
\hline \multirow[t]{3}{*}{ August } & 150 & Loam & 6.27 & 0.734 & 1.269 & 10.130 & 0.070 \\
\hline & Mean & - & 6.315 & 0.692 & 1.19 & 9.177 & 0.060 \\
\hline & 100 & Loam & 6.18 & 0.592 & 1.024 & 9.234 & 0.064 \\
\hline \multirow[t]{2}{*}{ September } & 150 & Loam & 6.26 & 0.766 & 1.325 & 10.665 & 0.073 \\
\hline & Mean & - & 6.22 & 0.679 & 1.174 & 9.949 & 0.068 \\
\hline
\end{tabular}

Table 5. Monthly physico-chemical conditions of pond bottom-soil (sediments) of pond no. 2 at two depths $(100 \mathrm{~cm}, 150 \mathrm{~cm})$ during the period of March to September 2012.

\begin{tabular}{|c|c|c|c|c|c|c|c|}
\hline \multirow[t]{3}{*}{ Months } & \multicolumn{2}{|c|}{ Physical factors } & \multicolumn{4}{|c|}{ Chemical factors } & \multirow{3}{*}{$\begin{array}{c}\text { Total } \\
\text { nitrogen } \\
\text { (\%) }\end{array}$} \\
\hline & Samplin & Soil textural & $\mathrm{pH}$ & Organic & Organic & Available & \\
\hline & $\begin{array}{l}\text { g depth } \\
\text { (cm) }\end{array}$ & class & & $\begin{array}{c}\text { carbon } \\
(\%)\end{array}$ & $\begin{array}{c}\text { matter } \\
(\%)\end{array}$ & $\begin{array}{c}\text { Phosphorus } \\
\text { (ppm) }\end{array}$ & \\
\hline \multirow{4}{*}{ March } & 100 & Sandy Loam & 6.29 & 1.166 & 2.017 & 8.425 & 0.108 \\
\hline & 150 & Sandy Loam & 5.90 & 1.421 & 2.458 & 11.233 & 0.126 \\
\hline & Mean & - & 6.10 & 1.293 & 2.237 & 9.829 & 0.117 \\
\hline & 100 & Sandy Loam & 6.26 & 1.221 & 2.112 & 9.286 & 0.112 \\
\hline \multirow{3}{*}{ April } & 150 & Sandy Loam & 6.18 & 1.243 & 2.150 & 10.234 & 0.121 \\
\hline & Mean & - & 6.22 & 1.232 & 2.131 & 9.76 & 0.116 \\
\hline & 100 & Sandy Loam & 6.22 & 1.098 & 1.8999 & 9.432 & 0.114 \\
\hline \multirow[t]{3}{*}{ May } & 150 & Sandy Loam & 6.16 & 1.344 & 2.325 & 11.456 & 0.123 \\
\hline & Mean & - & 6.19 & 1.221 & 2.112 & 10.444 & 0.118 \\
\hline & 100 & Sandy Loam & 6.33 & 1.221 & 2.112 & 11.456 & 0.116 \\
\hline \multirow[t]{3}{*}{ June } & 150 & Sandy Loam & 6.26 & 1.421 & 2.458 & 12.643 & 0.124 \\
\hline & Mean & - & 6.29 & 1.321 & 2.285 & 12.049 & 0.12 \\
\hline & 100 & Sandy Loam & 6.14 & 1.246 & 2.155 & 8.024 & 0.112 \\
\hline \multirow{3}{*}{ July } & 150 & Sandy Loam & 6.22 & 1.367 & 2.365 & 9.428 & 0.128 \\
\hline & Mean & - & 6.18 & 1.306 & 2.26 & 8.726 & 0.12 \\
\hline & 100 & Sandy Loam & 6.15 & 1.932 & 3.342 & 7.823 & 0.130 \\
\hline \multirow[t]{3}{*}{ August } & 150 & Sandy Loam & 6.24 & 1.841 & 3.185 & 10.354 & 0.143 \\
\hline & Mean & - & 6.19 & 1.885 & 3.263 & 9.088 & 0.136 \\
\hline & 100 & Sandy Loam & 6.16 & 1.456 & 2.519 & 12.347 & 0.170 \\
\hline \multirow[t]{2}{*}{ September } & 150 & Sandy Loam & 6.22 & 1.764 & 3.051 & 15.847 & 0.169 \\
\hline & Mean & - & 6.19 & 1.610 & 2.785 & 14.110 & 0.169 \\
\hline
\end{tabular}

Quantitative study of macro-zoobenthos The range of individual number of Oligochaeta (no. per $\mathbf{m}^{2}$ ):

Oligochaeta: Range of individual number of Oligochaeta (no. per $\mathrm{m}^{2}$ ) found in depth $100 \mathrm{~cm}$ was 89 to 133 and that found in depth $150 \mathrm{~cm}$ was 44 to 178 in pond no. 1 on monthly data during March to September 2012 (Table 7). Monthly individual number of Oligochaeta (no. per $\mathrm{m}^{2}$ ) found in depth of $100 \mathrm{~cm}$ was 44 and that found in depth of $150 \mathrm{~cm}$ was 89 in pond no.2 during March to September 2012 (Table 8). (no. per $\mathrm{m}^{2}$ ) found in depth $100 \mathrm{~cm}$ were 89 to 311 and the range of individual number of Oligochaeta (no. per $\mathrm{m}^{2}$ ) found in depth $150 \mathrm{~cm}$ were 44 to 400 in pond no. 3 on monthly data during March to September 2012 (Table 9).

Chironomidae: The range of individual number of Chironomidae (no. per $\mathrm{m}^{2}$ ) found in depth 100 $\mathrm{cm}$ were 444 to 622 and in depth $150 \mathrm{~cm}$ were found 533 to 755 in pond no. 1 on monthly data during March to September 2012 (Table 7). 
Table 6. Monthly physico-chemical conditions of pond bottom-soil (sediments) of pond no. 3 at two depths $(100 \mathrm{~cm}, 150 \mathrm{~cm})$ during the period of March to September 2012.

\begin{tabular}{|c|c|c|c|c|c|c|c|}
\hline \multirow[t]{2}{*}{ Month } & \multicolumn{2}{|c|}{ Physical factors } & \multicolumn{4}{|c|}{ Chemical factors } & \\
\hline & $\begin{array}{l}\text { Sampling } \\
\text { depth } \\
\text { (cm) }\end{array}$ & $\begin{array}{l}\text { Soil textural } \\
\text { class }\end{array}$ & $\mathrm{pH}$ & $\begin{array}{c}\text { Organic } \\
\text { carbon } \\
\text { (\%) }\end{array}$ & $\begin{array}{c}\text { Organic } \\
\text { matter } \\
(\%)\end{array}$ & $\begin{array}{l}\text { Available } \\
\text { phosphorus } \\
\text { (ppm) }\end{array}$ & $\begin{array}{l}\text { Total } \\
\text { nitrogen } \\
\text { (\%) }\end{array}$ \\
\hline \multirow{4}{*}{ March } & 100 & Silty clay Loam & 6.09 & 1.330 & 2.301 & 13.440 & 0.118 \\
\hline & 150 & Silty clay Loam & 6.17 & 2.060 & 3.564 & 17.151 & 0.180 \\
\hline & Mean & - & 6.13 & 1.695 & 2.932 & 15.295 & 0.149 \\
\hline & 100 & Silty clay Loam & 6.16 & 1.243 & 2.150 & 12.376 & 0.123 \\
\hline \multirow[t]{3}{*}{ April } & 150 & Silty clay Loam & 6.21 & 1.432 & 2.477 & 13.765 & 0.231 \\
\hline & Mean & - & 6.18 & 1.337 & 2.313 & 13.070 & 0.177 \\
\hline & 100 & Silty clay Loam & 6.20 & 1.098 & 1.899 & 11.378 & 0.145 \\
\hline \multirow[t]{3}{*}{ May } & 150 & Silty clay Loam & 6.32 & 1.523 & 2.635 & 13.690 & 0.256 \\
\hline & Mean & - & 6.26 & 1.310 & 2.267 & 12.534 & 0.200 \\
\hline & 100 & Silty clay Loam & 6.14 & 1.321 & 2.285 & 6.118 & 0.167 \\
\hline \multirow[t]{3}{*}{ J une } & 150 & Silty clay Loam & 6.23 & 1.643 & 2.842 & 5.315 & 0.145 \\
\hline & Mean & - & 6.18 & 1.482 & 2.563 & 5.716 & 0.156 \\
\hline & 100 & Silty clay Loam & 6.37 & 1.547 & 2.676 & 7.876 & 0.109 \\
\hline \multirow[t]{3}{*}{ July } & 150 & Silty clay Loam & 6.12 & 1.897 & 3.282 & 8.679 & 0.143 \\
\hline & Mean & - & 6.24 & 1.722 & 2.979 & 8.277 & 0.126 \\
\hline & 100 & Silty clay Loam & 6.23 & 1.436 & 2.484 & 8.378 & 0.050 \\
\hline \multirow[t]{3}{*}{ August } & 150 & Silty clay Loam & 6.34 & 1.789 & 3.095 & 9.985 & 0.110 \\
\hline & Mean & - & 6.28 & 1.612 & 2.789 & 9.181 & 0.080 \\
\hline & 100 & Silty clay Loam & 6.37 & 1.605 & 1.842 & 11.434 & 0.142 \\
\hline \multirow[t]{2}{*}{ September } & 150 & Silty clay Loam & 6.29 & 1.787 & 3.091 & 12.738 & 0.158 \\
\hline & Mean & - & 6.33 & 1.696 & 2.466 & 12.086 & 0.150 \\
\hline
\end{tabular}

The range of individual number of Chironomidae pond no. 1 during experimental period (Table 7). (no. per $\mathrm{m}^{2}$ ) found in depth $100 \mathrm{~cm}$ were 448 to Range of monthly individual number of 844 and in depth of $150 \mathrm{~cm}$ were 533 to 888 in Ceratopogonidae (no. per m2) found in depth of pond no. 2 on monthly data during March to $100 \mathrm{~cm}$ was 178 to 488 and that found in depth of September (Table 8). In pond no. 3 the number at $150 \mathrm{~cm}$ was 178 to 444 in pond no. 2 during depth $100 \mathrm{~cm}$ was 666 to 1066; and at depth 150 experimental period (Table 8). The range of $\mathrm{cm}$ the number was found as 111 to 1332 during monthly individual number of Ceratopogonidae this experimental period (Table 9).

Ceratopogonidae: The range of monthly individual number of Ceratopogonidae (no. per $\mathrm{m}^{2}$ ) found in depth of $100 \mathrm{~cm}$ was 310 to 666 and (no. per $\mathrm{m} 2$ ) found in depth of $100 \mathrm{~cm}$ was 266 to 755 and that in depth of $150 \mathrm{~cm}$ was 311 to 977 in pond no.3 during the period of this experiment (Table 9). that found in depth of $150 \mathrm{~cm}$ was 311 to 755 in

Table 7. Monthly fluctuations of macro-zoobenthos (no. per $\mathrm{m}^{2}$ ) with percentage in parenthesis under different groups of macro benthic fauna at two depths in pond no.1 during the period of March to September 2012.

\begin{tabular}{|c|c|c|c|c|c|c|}
\hline \multirow{2}{*}{$\begin{array}{l}\text { Sampling } \\
\text { months }\end{array}$} & \multirow{2}{*}{$\begin{array}{l}\text { Water } \\
\text { depths } \\
\text { (cm) }\end{array}$} & \multicolumn{4}{|c|}{ Quantity of Macro-zoobenthos (no. per $\mathrm{m}^{2}$ ) and \% } & \multirow{2}{*}{$\begin{array}{l}\text { Total no. of all } \\
\text { groups (100\%) }\end{array}$} \\
\hline & & Oligochaeta & Chironomidae & $\begin{array}{c}\text { Cerato- } \\
\text { pogonidae }\end{array}$ & Mollusca & \\
\hline \multirow[t]{2}{*}{ March } & 100 & $133(6.1)$ & $622(28.58)$ & $310(14.28)$ & $932(42.83)$ & 2176 \\
\hline & 150 & 133 (7.13) & $622(33.31)$ & 355 (19.03) & $755(40.45)$ & 1866 \\
\hline \multirow{2}{*}{ April } & 100 & $133(7.48)$ & $622(35.02)$ & $400(22.5)$ & $622(35)$ & 1776 \\
\hline & 150 & $89(5.01)$ & $666(37.5)$ & $400(22.5)$ & $622(35)$ & 1776 \\
\hline \multirow{2}{*}{ May } & 100 & $89(5.89)$ & $533(35.24)$ & $355(35.24)$ & $533(35.24)$ & 1510 \\
\hline & 150 & 89 (4.89) & 711 (39.03) & 355 (19.52) & 710 (39.03) & 1820 \\
\hline \multirow{2}{*}{ June } & 100 & - & 444 (37.03) & $310(25.92)$ & 444 (37.03) & 1199 \\
\hline & 150 & $44(2.35)$ & 755 (40.47) & $311(16.66)$ & 755 (40.47) & 1865 \\
\hline \multirow{2}{*}{ July } & 100 & $89(5.89)$ & $577(38.22)$ & $400(26.46)$ & $444(29.40)$ & 1510 \\
\hline & 150 & $178(10)$ & $533(30)$ & $488(27.5)$ & $577(32.5)$ & 1776 \\
\hline \multirow[t]{2}{*}{ August } & 100 & & $533(26.67)$ & 577 (28.89) & 888 (44.44) & 1998 \\
\hline & 150 & 89 (4.17) & $577(27.08)$ & $533(25)$ & 932 (43.75) & 2131 \\
\hline \multirow{2}{*}{ September } & 100 & & $577(27.08)$ & 666 (31.25) & 888 (41.67) & 2131 \\
\hline & 150 & $133(5.76)$ & $577(24.99)$ & 755 (32.69) & 844 (36.65) & 2309 \\
\hline
\end{tabular}


Table 8. Monthly fluctuations of macro-zoobenthos (no. per $\mathrm{m}^{2}$ ) with percentage in parenthesis under different groups of macro benthic fauna at two depths in pond no.2 during the period of March to September 2012.

\begin{tabular}{|c|c|c|c|c|c|c|}
\hline \multirow{2}{*}{$\begin{array}{l}\text { Sampling } \\
\text { months }\end{array}$} & \multirow{2}{*}{$\begin{array}{l}\text { Water } \\
\text { depths } \\
\text { (cm) }\end{array}$} & \multicolumn{4}{|c|}{ Quantity of Macro-zoobenthos (no. per $\mathrm{m}^{2}$ ) and \% } & \multirow{2}{*}{$\begin{array}{l}\text { Total no. of all } \\
\text { groups (100\%) }\end{array}$} \\
\hline & & Oligochaeta & Chironomidae & $\begin{array}{l}\text { Cerato- } \\
\text { pogonidae }\end{array}$ & Mollusca & \\
\hline \multirow[t]{2}{*}{ March } & 100 & $44(3.4)$ & 666 (51.71) & $355(27.57)$ & $222(17.23)$ & 1288 \\
\hline & 150 & $89(5.57)$ & 888 (55.57) & 178 (11.11) & 444 (27.78) & 1598 \\
\hline \multirow[t]{2}{*}{ April } & 100 & & 666 (42.86) & $222(14.28)$ & 666 (42.86) & 1554 \\
\hline & 150 & $44(2.42)$ & $666(36.59)$ & 266 (14.64) & 844 (46.35) & 1820 \\
\hline \multirow[t]{2}{*}{ May } & 100 & & 666 (42.86) & $311(20)$ & $577(37.14)$ & 1554 \\
\hline & 150 & - & $711(50)$ & 266 (18.75) & 444 (31.24) & 1421 \\
\hline \multirow{2}{*}{ June } & 100 & - & 844 (51.34) & $178(10.08)$ & $622(37.83)$ & 1643 \\
\hline & 150 & - & 888 (66.67) & 178 (13.33) & $266(20)$ & 1332 \\
\hline \multirow[t]{2}{*}{ July } & 100 & - & 488 (36.67) & 355 (26.67) & 488 (36.67) & 1332 \\
\hline & 150 & - & $533(37.49)$ & 266 (18.75) & 622 (43.74) & 1421 \\
\hline \multirow[t]{2}{*}{ August } & 100 & - & $533(30.76)$ & 444 (25.63) & 755 (43.58) & 1732 \\
\hline & 150 & - & 577 (30.29) & $577(30.24)$ & 755 (39.54) & 1909 \\
\hline \multirow[t]{2}{*}{ September } & 100 & - & $448(24.02)$ & 488 (26.19) & 888 (47.61) & 1865 \\
\hline & 150 & - & $577(30.94)$ & $444(23.80)$ & 844 (45.25) & 1865 \\
\hline
\end{tabular}

Table 9. Monthly fluctuations of macro-zoobenthos (no. per $\mathrm{m}^{2}$ ) with percentage in parenthesis under different groups of macro benthic fauna at two depths in pond no. 3 during the period of March to September 2012.

\begin{tabular}{llccrcc}
\hline \multirow{2}{*}{$\begin{array}{l}\text { Sampling } \\
\text { months }\end{array}$} & $\begin{array}{l}\text { Water } \\
\text { depths } \\
\text { (cm) }\end{array}$ & \multicolumn{2}{c}{ Quantity of Macro-zoobenthos (no. per m²) } & and \% & \multirow{2}{*}{$\begin{array}{c}\text { Total no. of } \\
\text { all groups } \\
\text { (100\%) }\end{array}$} \\
\cline { 3 - 5 } March & 100 & $311(15.21)$ & $800(39.14)$ & $355(17.38)$ & $577(28.24)$ & 2044 \\
& 150 & - & $1066(49.96)$ & $533(24.99)$ & $533(24.99)$ & 2133 \\
April & 100 & $89(4.66)$ & $1066(55.76)$ & $311(16.26)$ & $444(23.23)$ & 1911 \\
& 150 & $44(1.87)$ & $1332(56.56)$ & $311(13.19)$ & $666(28.28)$ & 2355 \\
May & 100 & $89(4.77)$ & $1021(54.75)$ & $311(16.67)$ & $444(23.81)$ & 1865 \\
& 150 & $89(3.58)$ & $1154(46.44)$ & $444(17.86)$ & $799(32.15)$ & 2486 \\
June & 100 & $133(7.14)$ & $1021(54.76)$ & $266(24.28)$ & $444(23.81)$ & 1865 \\
& 150 & $89(3.78)$ & $888(37.74)$ & $488(20.76)$ & $888(37.74)$ & 2353 \\
July & 100 & $89(4.35)$ & $932(45.66)$ & $400(19.57)$ & $533(26.10)$ & 2042 \\
& 150 & $89(3.85)$ & $888(38.46)$ & $400(17.31)$ & $932(40.36)$ & 2309 \\
August & 100 & $311(10.94)$ & $666(23.43)$ & $755(26.56)$ & $1110(39.06)$ & 2842 \\
\multirow{2}{*}{ September } & 150 & $400(10.58)$ & $111(29.41)$ & $977(25.88)$ & $1288(34.12)$ & 3774 \\
& 100 & - & $755(3148)$ & $755(31.48)$ & $888(37.03)$ & 2398 \\
& 150 & $222(9.09)$ & $755(40)$ & $577(23.64)$ & $666(27.27)$ & 2442 \\
\hline
\end{tabular}

Mollusca: Range of monthly individual number of Mollusca (no. per $\mathrm{m}^{2}$ ) found in depth of $100 \mathrm{~cm}$ was 444 to 932 and that in depth of $150 \mathrm{~cm}$ was 577 to 932 in pond no. 1 during this experiment (Table 7). Range of individual number of mollusca (no. per $\mathrm{m}^{2}$ ) found in depth of $100 \mathrm{~cm}$ was 222 to 888 and that in depth of $150 \mathrm{~cm}$ was 266 to 844 in pond no. 2 during this experiment (Table 8). The range of individual number of Mollusca (no. per $\mathrm{m}^{2}$ ) found in depth of $100 \mathrm{~cm}$ was 444 to 1110 and that found in depth of 150 $\mathrm{cm}$ was 533 to 1288 in pond no. 3 during the experimental period (Table 9).

Relationship of macro-zoobenthos with physico-chemical parameters of the ponds

In pond nos. 1, 2 and 3 correlation coefficients ( $\mathrm{r}$ value) between macro benthos density (no. per $\mathrm{m}^{2}$ ) and water temperature $\left({ }^{\circ} \mathrm{C}\right)$, transparency $(\mathrm{cm})$, rainfall (mm), D.O. (ppm), free $\mathrm{CO}_{2}$ (ppm), total alkalinity (ppm), $\mathrm{NO}_{3}-\mathrm{N}(\mathrm{ppm})$ and $\mathrm{PO}_{4}-\mathrm{P}$ (ppm) indicate negative relations except some positive relations; there is no statistically significant value.
In pond no. 1 correlation coefficients ( $\mathrm{r}$ value) between macro-zoobenthos (no. per $\mathrm{m}^{2}$ ) and $\mathrm{D}$. O. (ppm), $\mathrm{NO}_{3}-\mathrm{N}(\mathrm{ppm})$ and $\mathrm{PO}_{4}-\mathrm{P}(\mathrm{ppm})$ are positive and the correlation coefficients between macro-zoobenthos (no. per $\mathrm{m}^{2}$ ) and water temperature $\left({ }^{\circ} \mathrm{C}\right)$, rainfall $(\mathrm{mm})$, transparency $(\mathrm{cm})$, total alkalinity (ppm) and free $\mathrm{CO}_{2}$ (ppm) are negative.

In pond no.2, correlation coefficients ( $\mathrm{r}$ value) between macro-zoobenthos (no. per m2), free $\mathrm{CO}_{2}(\mathrm{ppm}), \mathrm{NO}_{3}-\mathrm{N}(\mathrm{ppm})$ and $\mathrm{PO}_{4}-\mathrm{P}(\mathrm{ppm})$ are positive and relations between macro-zoobenthos (no. per $\mathrm{m}^{2}$ ) and D. O. (ppm), water temperature $\left({ }^{\circ} \mathrm{C}\right)$, transparency $(\mathrm{cm})$ and rainfall $(\mathrm{mm})$ are negative.

In pond no. 3, correlation coefficients ( $\mathrm{r}$ value) between macro-zoobenthos (no. per $\mathrm{m}_{2}$ ) and water temperature $\left({ }^{\circ} \mathrm{C}\right)$, free $\mathrm{CO}_{2} \quad(\mathrm{ppm})$, transparency $(\mathrm{cm})$, and $\mathrm{NO}_{3}-\mathrm{N}(\mathrm{ppm})$ are positive and relations between macro-zoobenthos (no. per $\mathrm{m}^{2}$ ) and D. O. (ppm), $\mathrm{PO}_{4}-\mathrm{P}(\mathrm{ppm})$ and total alkalinity (ppm) are negative. 
Habib et al. (1987) stated that the combined effect of rainfall, temperature and transparency of water upon the growth of benthic fauna was significant only in case of Viviparous bengalensis. The growth and abundance of Culicoides sp. exhibited high inverse relation with water temperature.

Relationship of macro-zoobenthos with chemical parameters of bottom soil of three ponds

In pond nos. 1, 2 and 3 correlation coefficients ( $\mathrm{r}$ value) of macro-zoobenthos (no. per m2) with chemical parameters of pond bottom soil $(\mathrm{pH})$, organic carbon (\%), organic matter (\%), available phosphorus ( $\mathrm{ppm})$, and total nitrogen (\%)are positive in most cases except some negative relations.

In pond no. 1 correlation coefficients between macro-zoobenthos (no. per $\mathrm{m}^{2}$ ) and total nitrogen (\%) are statistically insignificant. In pond no. 2, correlation coefficients between macrozoobenthos (no. per $\mathrm{m}^{2}$ ) and total nitrogen (\%) are statistically significant. In pond no. 3, correlation coefficients between macrozoobenthos (no. per $\mathrm{m}^{2}$ ) and total nitrogen (\%) are statistically significant. Habib et al. (1984) found significant correlation of Peopia, Chironomus and Viviparous sp. with multiple effect of $\mathrm{pH}$, organic carbon, total nitrogen and available phosphorus of bottom soil. He also found that most of the chemical properties of bottom soil were directly correlated with each other in the ponds.

\section{Abundance of macro-zoobenthos and soil textural class of pond bottom mud}

The highest abundance of macro-zoobenthos (no. $/ \mathrm{m}^{2}$ ) was found in silty clay loam (pond no. 3 ) in which range of macro-zoobenthos was 1865 to 3774 no./ $\mathrm{m}^{2}$; and that lower than this was found in loam (pond no. 1) in which range of macrozoobenthos was 1510 to 2309 no. $/ \mathrm{m}^{2}$; and the lowest abundance of macrozoobenthos was found in sandy loam (pond no. 2) in which range of macro-zoobenthos was 1288 to 1909 no./ $\mathrm{m}^{2}$. It is clear that soil textural class, silty clay loam is better than loam and loam is better than sandy loam for growth and production of macro benthic fauna. Nupur (2011) found slightly different result in research on benthos in 3 ponds in which the highest macro-zoobenthos population density $\left(\right.$ no. $\left./ \mathrm{m}^{2}\right)$ was in loam followed by that in clay loam and the lowest was in sandy loam.

\section{Conclusion}

From the result of this experiment, it is clear that the relationship between macro-zoobenthos density and physical parameters of the ponds of this experiment indicate negative relations in most cases. Relationship between macrozoobenthos density and chemical parameters were positive in most cases. Soil texture of the pond bottom has relationship with the abundance of macro-zoobenthos. The results of study showed that soil textural class silty clay loam is better than loam, and loam is better than sandy loam for the growth and production of macro benthic fauna.

\section{Acknowledgement}

This research was conducted as part of M.S. Thesis of Begum Rebeka Irin in the Department of Fisheries Management, Faculty of Fisheries, Bangladesh Agricultural University, Mymensingh-2202, Bangladesh.

\section{References}

APHA. 1971. Standard methods for the examination of water and wastewater. 17th edition. American Public Health Association, Washington, D.C. USA. $2036 \mathrm{p}$.

Bernotiene, R. and Visinskiene, G. 2007. The diversity of benthic invertebrates in three rivers in Lithuania. Acta-BiologicaUniversitatis-Daugavpiliensis. 7 (2): 87-96.

Brinkhurst, R.O. 1974. A guide for the Identification of British Aquatic Oligochaeta, Freshwater Biological Association, Scientific Publication No. 22 and 55.

Das, M. and Islam, M. A. 1983. A study on the macro benthos of an artificial pond in the Agricultural University campus. Bangladesh J. Aqua. 2-5 (1): 1-11.

Dewan, S. 1973. Investigation into the ecology of fishes of Mymensingh Lake. Ph.D. Thesis. Department of Aquiculture and Management, Faculty of Fisheries, Bangladesh Agricultural University, Mymensingh, Bangladesh. 353 p.

Habib, M.A.B., Ahmed, A.K.M. and Islam, M.A. 1984. Status of macro-benthos in two ponds in Bangladesh Agricultural University Campus, Mymensingh, Bangladesh. Bangladesh J . Agril. Sci. 11(1): 39-46.

Habib, M.A.B., Ahmed, M. and Haque, A.K.M.A. 1987. Effect of bottom soil conditions on the growth and abundance of benthic fauna of two ponds. Bangladesh J. Fish. 10 (1): 45-47.

Khan, M.H. 1990. Studies on the population dynamics of benthic macro invertebrates in two fish ponds. M.S. Thesis. Department of Fisheries Biology and Limnology, Bangladesh Agricultural University, Mymensingh, Bangladesh. 58 p.

Nupur, N.F. 2011. Fortnightly variations of benthos in relation to limnological conditions of three ponds. M.S. Thesis, Department of Fisheries Management, Bangladesh Agricultural University, Mymensingh, Bangladesh. $82 \mathrm{p}$.

Rahman, M.S. 1992. Water quality management in aquaculture. BRAC Prokashana, 66, Mohakhali, Dhaka, Bangladesh. 84 p.

Sattar, M.A. and Rahman, M.M. 1987. Techniques of Soil Analysis. Published by A. Sattar, Bangladesh Agricultural University, Mymensingh. $54 \mathrm{p}$. 